\title{
THE IDEAS OF THE SECOND ECUMENICAL COUNCIL OF THE VATICAN: THE UNITY OF THE PAST AND THE PRESENT
}

\author{
Bodak V. A.
}

\section{INTRODUCTION}

The need for a reflection on the ideas of the Second Vatican Council (1962-1965) revealed contradictory processes occurring in Catholicism: the conflict between religion and culture and, at the same time, the attempt to find a compromise, an optimal solution to the question of the place and role of religion in the modern world.

The Second Vatican Council in Catholic and inter-denominational context is a phenomenon not only of theological but also of historical and cultural content and significance. In particular, the very fact and results of the Council led to changes in the internal and foreign policy of the Roman Catholic Church in the system of Church-layman relations, Church-State, ChurchChurch, a new stage in the development of the UGCC in exile, and eventually in the independent Ukraine, as well as major shifts in the promotion of freedom of religion and faith. The problem of enculturation is linked with the problem of dialogue between the Churches, Church and culture, the mutual influence of religion on culture and culture on religion as a process of inclusion of an individual to culture, assimilation of existing habits, norms and patterns of behavior inherent in this culture.

The presence of the Ukrainian delegation at the Council, headed by J. Slipyi, his two-hour report on the role and significance of the church, the grievances suffered by laymen and clergy in the USSR on the basis of faith contributed to preserving the identity of Ukrainians at home and in the diaspora. These questions, in their content, were a manifestation of the enculturation in the system of relations between Ukrainian Greek Catholic and Roman Catholic world, also augmenting the Council a cultural, social and political meaning and sound. The Metropolitan's report drew the attention of the Catholic world to understanding the problems of the UGCC in the postwar period in the underground in the USSR and in the Diaspora, and greatly contributed to its revival in 1989 in Ukraine.

Today, the problem under study is particularly relevant for the Ukrainian community, as contemporary reading of the materials ${ }^{1}$ and analysis of the Council's ideas help to comprehend religious ideals and values in the realities

${ }^{1}$ Документи Другого Ватиканського Собору. - Львів: Свічадо, 2014. - 606 с. 
of Ukrainian and world culture, and also help to shape our national and European cultural identity.

\section{Theoretical basis for understanding the problem}

Domestic religious studies actively develop problems of enculturation, interfaith relations in Ukraine and the world, the main tendencies of the dynamics of religious and cultural interaction. In particular, P. Yarotsky analyzes the specifics of the Ukrainian confessional context, contemporary inter-confessional relations in Ukraine, A. Kolodnyi, L. Filippovych, O. Nedavnya, V. Matveev, study the content and mechanisms of dialogue of cultures in the modern Christian world, V. Lentsy, V.Yelensky, V. Pashchenko and a number of others highlight the formation and development of the UGCC under the influence of the events of the Second Vatican Council and its cultural and historical significance in the past and present.

The New Testament calls the love of God the primary commandment of Jesus, as well as the love of one's neighbor and even of one's enemies. Preaching and cultivating such unselfish and unconditional love, which harmonizes man and the world, helps man to rise in his development to incredible heights. In Christianity, a believer learned to enter into a state of boundless love from the very beginning of spiritual practice. Thanks to the preaching of love, Christianity very quickly won the hearts of millions of citizens in the Roman Empire at the dawn of its history. But for a living in a globalized world modern man, who comprehends "objective reality" by means of his own and artificial intelligence, one preaching of love is no longer enough. This fact triggers the Catholic Church's efforts to adapt Christianity to the modern world in the process of enculturation and interaction.

After the Second Vatican Council, Catholic theologians began to perceive the picture of the world not only in the form of matter enlivened by the spirit of God, but also in the form of matter active and dynamic, acting and developing, defining it as far as possible in scientific terms. This attribute "Ajornamento" is connected with the philosophical and theological heritage of P. Teilhard de Chardin, as well as the philosophical concepts of J. Maritain who substantiated the concept of "theocentric humanism", the principles of spiritual revival of the Catholic Church, its humanization, the glorification of man in the heritage of Charles Péguy and others.

"Theology of Culture" is the basis for a Catholic understanding of ecumenism, that is, a policy of convergence of all religions under the auspices of the Vatican throne. In practice, this is reflected in the extremely high missionary and diplomatic activity of the Vatican in recent years, in particular in non-Christian countries where Holy See envoys participate in local rites 
and ceremonies, thus honoring the shrines worshiped in these religions. An example of this is a document prepared as a summary of the Special Assembly of the Synod of Bishops, which is dedicated to the Amazon region. The Synod was called in October 2019, and Pope Francis' post-synodal Apostolic Reminder of the Church with an Amazon Face was published on February 12, 2020 under the title "Querida Amazonia". In his speech, the Holy Father addresses the four dimensions of the Synod: enculturation, ecology, social issues, and pastoral care. At the same time, he drew attention to the creativity of new ministries, the role of women in the Amazon culture, the missionary ministry of priests in the countries of the Amazonian region, and the preservation of local culture in relation to others ${ }^{2}$.

Enculturation requires differentiation - the differentiation that becomes possible through theological consciousness. Therefore, in any enculturation, the role of the Church is of utmost importance. The Church is called to make sure that new cultural forms, without distortions, embody the basic existential truths that preach the gospel of Christ to the world.

Theology seeks to provide the Church with fundamental guidelines that allow it to make judgments in each case about which cultural forms correctly embody the gospel and which, in fact, is the expression of "another gospel". The Church seeks to apply theological rather than simply ethical criteria, since the latter often coincide with the cultural ones. If, for example, the question arises: whether magic or polygamy in the African cultural context are ethical elements and can be combined with the essence of the Gospel, then one can only answer it by knowing what the essence of the Gospel is. And this knowledge informs the theological consciousness of the Church.

As P. Yarotsky rightly remarked, the "enculturated" church of tomorrow is a synthesis of great cultures and philosophies adapted to the Gospel. If such a project is implemented, then humanity in the XXI century may, in fact, meet with a new universal religion",3.

In Catholic theology, the point of view, historically dominated by the principle formulated by St. Cyprian of Carthage (in fact, this thought can be found in Origen of Alexandria in the III century): "extra ecclesiam nulla salvus" - outside the Church there is no salvation. The word "Church" in the past meant the Roman Catholic Church.

2 «Querida Amazonia». Післясинодальне Апостольське напоумлення Папи Франциска від 12 лютого 2020 року // Пресслужба Секретаріату Синоду Єпископів УГКЦ (за матеріалами: VaticanNews). - URL: https://synod.ugcc.ua/data/querida-amazoniaapostolske-napoumlennya-pro-tserkvu-z-amazonskym-oblychchyam-2425/

${ }^{3}$ Яроцький П.Л. Етноконфесійна толерантність - морально-етичний дискурс третього тисячоліття // Християнство і мораль. - Тернопіль, 2002. - С. 90. 
This view was radically changed last century, especially after the Second Vatican Council, by means of the idea of different degrees of communion: those who belong to the Roman Church are in full communion with the Church, while those who are outside the Roman Catholic Church only partially abide in the Body of Christ.

\section{The leading ideas of the Second Vatican Council}

The Second Ecumenical Council of Vatican of the Catholic Church proclaimed the idea of "agiornamento" ("modernization", "restoration" of the Church), carried out revolutionary liturgical and canonical reforms, which resulted in a sharp turn in the bosom of the Roman Catholic Church towards modernization of worship, to intensification of the ecumenical tendencies in modern liberal Catholic theology. Undoubtedly, the Second Vatican Council gave legitimacy to the process of formation of the complex phenomenon that we have in mind today when referring to the social doctrine of Catholicism, which is directly related to the teaching of the Catholic Church on enculturation. The social doctrine of modern Catholicism is a set of provisions and principles in the light of which the church seeks solutions to problems pertaining to social life, in particular, its political, economic, cultural, and moral aspects.

The social doctrine of the Catholic Church, as Yu. Mayka notes, puts forward a triple set of provisions that make up the general system:

- provisions relating to the nature of the relationship that arises between a person's desire for God and his secular (political, economic, and social) activity;

- provisions, the content of which is a critical analysis of the existing social reality;

- the Church's recommendations regarding reconciling socio-economic and political criticism with the norms of religious morality ${ }^{4}$.

From the first to the last day of his work, the center of attention of the Council was the problem of restoration (agiornamento) of this life of the Church considering both its historical experience and traditions, and the conditions of life at the turn of the millennium. In the Constitution for the Holy Liturgy, the Council spoke in favor of the diversity of the liturgical typology in accordance with different traditions and cultures, as well as in the simplification of rites. Territorial ecclesiastical authorities have the right to make decisions about the use of modern local languages (while maintaining the ability to serve mass and Latin). On December 7, 1965 The Declaration of

${ }^{4}$ Майка Ю. Социальное учение Католической Церкви. - Рим - Люблин, 1994. C. 22-23. 
Religious Freedom was adopted recognizing the right to choose religion for each individual. The history of the Church did not yet know such a bold step. The recognition of the principle of freedom of conscience was not easy for Catholicism. It was on the basis of an expanded interpretation of freedom of conscience that the participation of the Catholic Church in the ecumenical movement became possible.

The liturgical reform of 1969 was the result of the Second Vatican Council. The Second Vatican Council allowed the traditional Latin Mass to be translated into national languages as sanctioned by the local bishops' conference and to replace the old liturgical texts with the new ones, which was done in the next 10-15 years in all Catholic countries. The liturgical modernization in the Catholic Church is justified by "missionary goals", the desire to bring service closer to the people, and return to the ancient practice of the Church.

However, the traditionalist Catholic clergy, led by Archbishop M. Lefebvre, did not accept the modernist reforms that broke with one and a half thousand year old tradition of Western Latin worship. Lefebvre actively advocated the preservation of traditional teaching and worship, the inadmissibility of modernism, liturgical reforms, in particular, Latin translations of liturgical texts. Archbishop Lefebvre believed that after admitting to the liturgical practice of the various canons of the Mass, the very variability, anarchic ability to choose from the whole set of these texts, "what is more pleasing," destroys the pious attitude of worship as an instruction of God. It is impossible to profoundly change the "law of prayer" without reforming the "law of faith". The archbishop's active opposition to the Church's reform efforts led to his excommunication in July 1988.

A sign of modern Catholic ajornamento is Vatican's ecumenical policy, and its foundations were also laid at the Second Vatican Council. The activities of the Roman Pope John Paul II will undoubtedly go down in the history of the Catholic Church with its ecumenical purposefulness. The Catholic principles of ecumenism, formulated in the documents of the Second Vatican Council (Decree on Ecumenism "Unitalis Redintegratio"), have been revealed in numerous letters, speeches to the Christians around the world, religious documents of the RCC. The encyclical on ecumenical duty "Ut unum sint" summed up the ecumenical activities of the RCC on the eve of the third millennium, and set a goal - to move forward through ecumenical dialogue. But the path of ecumenical movement is complex and long-lasting. In return for the exaltation of the first years after the Second Vatican Council,

\footnotetext{
5 Архиепископ Марсель Лефевр и католицизм XX века // Regnum Aeternum. - Т. I. Париж, 1996.
} 
when it seemed that any misunderstanding between Christians had already ended, came hard work in every corner of the world.

Catholics consider the last decade of the XX century to be a period of "realism" in assessing the prospects for unity. During this period, the Catholic Church realized the complexity of the process of unity and ascertained the fact that the restoration of unity is a gift of God, which does not depend on human effort.

Christian humanism and human theology appear in the theory and practice of the Ajornamento in close connection with the problem of culture, which is regarded as an expression of the spiritual life of man and his being. "Man, notes John Paul II, is the primordial and fundamental phenomenon of culture ... in the totality of its spiritual and material subjectivity" ${ }^{\prime \prime}$. According to the Pope, every nation has the right to civilization and culture, regardless of race, gender, nationality, religion or social status.

But it is clear from the basic documents of the Catholic Church that the culture of the modern mankind is in a state of crisis. The crisis of culture is linked to the crisis of religion, and this of course raises alarm in the Christian world. The term "crisis" is increasingly used to refer to faith in the Almighty, position in the Churches, and in the broad sense, religion in the modern world. Such sentiments are generated by the continuing decline of faith, the displacement of Christian moral norms and the lack of spirituality in the cultural - civilizational sphere. In the apostolic message "Tertio millenio adviente" (1994), attention is paid to the growing indifference to religion, to the disappearance of the transcendental understanding of human existence, to the strengthening of the spirit of secularism and ethical relativism, to the emergence of "false theologies", to the disobedience of churches.

Modernized Catholicism recognizes the danger of the processes of secularization of all spheres of public life that swept the world at the end of the $20^{\text {th }}$ century. Catholics see a way out of this situation in their appeal to the biblical foundations of human life. On the one hand, it signifies strengthening of faith among the inhabitants of the regions where Christianity came centuries ago. Ajornamento seemingly purports to bring these peoples back to Christian norms and re-Christianize them; on the other hand, to direct the choice of non-believers to Christianity. The most important role in solving these major tasks of Catholicism is given to the "preaching of the social doctrine of the Church" because, according to

\footnotetext{
${ }^{6}$ Иоанн Павел II. Мысли о земном / Иоанн Павел II. - М. : Новости, 1992. - 424 с. C. 198-199.
} 
Pope John Paul II, "there is no true solution to the" social question "outside the Gospel".

The Catholic Ajornamento proceeds from the fact that "the foundations of the natural law and truth of Revelation, as the two are by no means opposite, but equidistant waterfalls, have their common source in God," and are found in one, Christ-saved human personality. The specific human nature created by God is being correlated with Christ and included in a system of salvation that encompasses the natural and the supernatural. The modernization of modern Catholicism touches upon the traditional Christian understanding of the Church as a God-human organism, instead of which there is an understanding of all cultures of humanity, developed by official "theology of culture", as relatively spiritually equivalent.

The new teaching of the Second Vatican Council on the nature of the Church is most fully stated in the Pastoral Constitution on the Church in the modern world, often called the first words "Gaudium et spes" ("Joy and Hope"), and which can be called the pinnacle of the "Ajornamento". In the religious-ethical concepts here are presented all those changes that have occurred in the public and in the personal life of people. We are talking about a Church that helps people who want to contribute to social progress, strives to present the ideals and goals that it offers to modern man as ideals and goals that emerge from his practical life and meet his practical interests, recognize all that is positive that is present in modern social dynamism, especially - the evolution towards unity and the process of healthy socialization (Gaudium et spes $-\S 42)$.

A striking example of the modernization process of enculturation is the activity of the RCC in Ukraine. The socially-active Catholic policy of enculturation, which has been successfully developing and consistently being modernized in the Ukrainian territory, is proving quite attractive to believers. This is evidenced by the steady increase in the number of RCC and UGCC communities in the country in recent years, particularly in the western regions. As A.M. Kolodnyi notes, "we live in the face of accelerated social progress. A faith that wants to survive, to keep up, must change according to our time, its needs, and its prospects ... Of course, the Church, which has a good tradition, can count on more success because it does not have to rebuild everything, repeat past mistakes, unpromising actions ... Catholicism, as a powerful spiritual movement of our time and one of the most dynamic Christian denominations, has great reasons to dominate the religious life of the next century. The guarantor of this is not only the ajornamento spirit, lack of rigidity, but also openness to different cultures, high appreciation of the desire of the mind to know the true truths of Christ, encouragement of the 
laity to be more active in overcoming hypocrisy, which is manifested in the formal performance of ritual actions" $"$.

When developing its social projects the Ukrainian Greek Catholic Church builds on the experience and basic documents the RCC. However, the successful deployment of its public programs is hampered by several problems that in some way impede the fulfillment of the UGCC's social and creative mission. The first aspect is related to the need to find out the place of the UGCC between the Orthodox and the Catholic Church of the Latin rite. It was believed that being on the verge of two cultures Greek Catholics are in a special situation, and therefore have a special task in synthesizing the social approaches of East and West. However, the fact of borrowing elements of another culture without proper enculturation and aligning with the vital forces of own culture can become a kind of eclecticism.

It is important to dwell in more detail on the culturological aspect of enculturation. The transformations that were taking place in Catholicism, of course, are well and seriously argued by theologians and, in their view, simplify the practice of enculturation of Christianity in the modern world.

The Second Vatican Council highlighted two points on the basis of which the Church pays great attention to the culture of different peoples and civilizations. Firstly, culture "directly derives from the rational and social nature of man" (No. 59, §2). "To raise the human personality, as the Council wants, is to show special attention to the unique and necessary expression of the personality that is culture." Secondly, the preaching of the Gospel in the context of a certain chronotope of culture ensures that it is understood in accordance with the standards of perception of that culture. "There are numerous links between salvation news and human culture. Because God, manifesting Himself to His people in such a way that He even incarnated in Son, spoke to the appropriate culture inherent in each era," - so justifies the Council the need to take into account the particularities of local cultures. Pope John Paul II emphasized that people express themselves through culture and form their own consciousness on its basis. That is why the Church, in attempt to adapt to any form of human society and "mastering everything that is valuable in the customs and different forms of life of peoples" (No. 13, § 2), needs to know and appreciate different cultures, with an understanding of using them to bring to the people the Good News. Therefore, the Church, having existed for centuries under different conditions, takes advantage of the achievements of different cultures to spread and express the message of Christ

\footnotetext{
${ }^{7}$ Колодний А.М. Проблеми і перспективи християнства ХХІ століття // Християнство: контекст світової історії і культури. Науковий збірник конференції / Ред. кол.: А.М. Колодний П.Л. Яроцький та ін. - Київ, 2000. - С. 55-56.
} 
in the communication of believers and in the diverse life of society "(No. 58, $\S \S 1,2)$.

The historical reality is that culture is heterogeneous. This forces its subjects to seek dialogue and understanding. In addition, the Church is confronted with the task of enculturation, that is, in translating the Gospel ideas into a culture-specific language. However, difficulties arise when not only the picture of the world in a given culture differs from Christianity, but also the values and traditions of culture which are contrary to the ideas of Christianity.

The Church wants to speak the language of culture, but in the case of the antagonistic nature of fundamental precepts of culture and religion (such as contemporary pop-culture), it is difficult to speak the language, if at all possible. In addition, if there is a clear inconsistency with the doctrines of the Church and the essence of the Gospel, the Church will not be able to say anything in the language of culture or any other language other than the truth - where, at what point, the views, goals, and values of that culture do not coincide with those of the Gospels. Therefore, the process of enculturation cannot be very simple. It can be conflict-free only outside the dogma, that is, if it is only about acquainting cultures with one another, but not about transcendental goals and values, not about acceptance by any cultures of Christianity. Adopting Christianity as a culture or cultural subject will, first and foremost, mean abandoning those traditions, the worldview, and the belief that existed in the culture before.

The enculturation of Christianity into contemporary culture, even in areas where it is a traditionally, historically formed religion, is also one of the tasks of the Catholic ajornamento. The encyclical Faith and Reason states: "Our generation is confronted with the problems that the Church had to address in the first centuries of its existence" (Ch. VI, 72). Modern culture is often too far from the Gospel ideal and its moral from morality. Nevertheless, the Catholic Church perseveres in its attempt to find the very language that modern culture will hear.

In the representational forms and content of culture, it is important to highlight not only the substantive side of a religious idea, but also its refraction in different cultures, to identify meaningful and significant changes. The process of such refraction is also interesting because most often the dialogue of cultures begins with the dialogue of ideas including religious. Linguistic, semantic and semiotic specific cultural meanings cannot be adequately translated, although in the process of communication of representatives from different cultures, ideas change acquiring sense and comparing themselves with the cultural institutions of their carriers. It is necessary to take into account the specificity of the cultural 
representatives, bearing in mind that not only changes in it cause similar changes in its representatives, but the latter affect the culture in the form of feedback.

When asked whether there is a Christian culture, that is, a culture that needs to be spread throughout the world in the name of Christ, the Catholic Church answers negatively. According to theologians, the Gospel was significantly harmed when a church mission was understood as spreading and planting a particular culture. This does not mean that the gospel, in order to be preached, must be completely separate from all forms of culture. This means that the Christian mission must respect the will of the people to express their faith in their own way, at the same time paying attention to being faithful to the substance of the gospel message. It is worth mentioning the words of Pope John XXIII, said at the opening of the Second Vatican Council on October 11, 1962: “ $\ldots$ one thing is the basis of true faith contained in our true teaching, another is the way in which these truths are expressed, while fully maintaining the same content and meaning "(No. 62, § 2).

At the beginning of his pontificate, John Paul II, addressing all people of good will, touched upon this particular topic: "All the ways of the Church lead to man, and each man thus proceeds the way of the Church, the path of his life and daily experience, his purpose and work. The Church of our time must be aware of all its responsibility for the position of man ... The Church seeks to serve the sole purpose: that every man may find Christ and that Christ, by the power of the truth about man, by the power of love emanating from Him, become a companion of every person on the path of his being". The Church's internal culture (new language, new forms of communication) takes an auxiliary position: not to try to tear a person out of the context of his or her culture or subculture, but to offer the answers to those aspects of a steady intrinsic church tradition that he is ready to accept. This is a complex task of the interaction of religion and culture.

Striving to connect with a person of a new culture, the Church does not allow dissolution in the culture, but, on the contrary, wants to introduce innovations in it. But here it is confronted with science and the consequences of the superiority of the scientific worldview. The man of science is selfopinionated relying on human effort and easily stating that he does not need God: this is the very atheistic "Promethean" humanism that is now almost officially recognized as the norm of thinking. "One may fear," notes the Second World Council, "lest a person, unduly trusting in modern inventions, should feel self-sufficient and ceased to seek higher values" (No. 57, § 5).

The theme of enculturation in Catholicism sounds like taking into account the cultural situation both in Christian countries and in other cultural traditions; for the Protestants the form becomes unimportant to such an extent 
that it practically loses its sacred content; for the Orthodox the real need of any culture in the Christian religion is so high that the culture must rise to the Gospel, what the Church promotes in every possible way, and religion should seek a way for it into the minds and hearts of the modern man, adapting to what is understandable and familiar to him. However, culture does not require the introduction of a new empire, but the introduction of new senses, which, in fact, is a successful, purposeful enculturation that was once accomplished by the apostles. In the culture of the XXI century, rationally minded and welleducated people and a society who know about Christianity as an idea, about a Christian cult, about religious art, more than ever need an answer to the question "why is that all this?" And only the answer to this question with further realization will make this "Christianization of culture" and, similarly, a successful enculturation possible.

In any culture, constant value, symbolic and energetic transformations take place. It is a natural process in a cultural environment. Filling it with valuable contents, revealing the hidden or as-yet unheard is the essence of reality, largely independent of the purposeful efforts of individuals or elites. This process is also self-organizing. It is important however, what values the culture will prefer. It will depend on its viability and the way of its further development. Enculturation in the Catholic and Protestant versions is the introduction of gospel truths into the culture. But whether or not culture accepts it depends not so much on the efforts of the missionaries and the form of the idea, but on how much the culture really needs this truth. Based on the experience of the Church, enculturation successfully occurs only there and then when it should take place.

\section{CONCLUSIONS}

Regardless whether we admit it or not, our current cultural situation clearly reveals a deep crisis of obvious and accepted concepts, divergences of values in different fields of knowledge, contradictions and gaps between different systems of reference in culture, clashes of worldviews, and most often, intolerant attitude to other people's opinion, rejection of systematic and holistic dogmatism. It is only through a great joint effort by people who seek dialogue who are equally educated in the spiritual and secular spheres of culture it is possible to overcome this crisis. At present, the noblest ascension without some intellectual training will not be sufficient for a serious dialogue of cultures in the modern world, where cultural orientation is clearly hidden or counteracting the commandments of the Beatitudes.

The movement of the Catholic Church into the world, the symbol of which became the Second Ecumenical Council, caused changes in the field of pastoral ministry, the internal causes and practical significance of which were 
not clearly ascertained. As with the ecumenical movement, after coming to understand the inability to dissolve in another culture or absorb it, the meeting of the Church and the world is accompanied by difficulties within a society that sometimes rejects faith. It has to choose a path that is in line with scientific and technological progress, socio-political aspirations, and changes in moral and religious order. This is the essence of the task that the new culture now puts before religion.

The ideas of the Second Vatican Council are highlighted in the materials published in 2014 in the Ukrainian language translated from Latin ${ }^{8}$ that define the modern understanding of the role of the Church in social and personal life. And it is not just about the Catholic Church, since the Council was an event that in the twentieth century initiated the renewal of the Church of Christ in the new civilizational conditions, testified to its openness to participate in solving problems of man and society.

\section{SUMMARY}

The proposed materials bring to life and substantiate the ideas of the Second Vatican Council, which determine the contemporary understanding of the role of the Church in social and personal life. And it is not just about the Catholic Church, since the Council is an event that in the twentieth century initiated the renewal of the Church of Christ in the new civilizational conditions, testified to its openness to interaction, participate in solving urgent problems of man and society.

\section{REFERENCES}

1. Архиепископ Марсель Лефевр и католицизм XX века // Regnum Aeternum. - Т. І. - Париж: Б.И., 1996. - С. 221-232.

2. Бодак В. Релігія i культура: взаємодія та взаємовплив : [монографія] / В. Бодак. - Київ-Дрогобич : Коло, 2005. - 305 с.

3. Документи Другого Ватиканського Собору. - Львів: Свічадо, 2014. $-606 \mathrm{c}$.

4. Иоанн Павел II. Мысли о земном / Иоанн Павел II. - М. : Новости, 1992. $-424 \mathrm{c}$.

5. Колодний А.M. Проблеми i перспективи християнства XXI століття // Християнство: контекст світової історії і культури. Науковий збірник конференції / Ред. кол.: А.М. Колодний П.Л. Яроцький та ін. - Київ, 2000. - С. 55-56.

6. Майка Ю. Социальное учение Католической Церкви / Ю. Майка. Рим - Люблин, 1994. - С. 22-23.

\footnotetext{
${ }^{8}$ Документи Другого Ватиканського Собору. - Львів: Свічадо, 2014. - 606 с.
} 
7. Яроцький П.Л. Етноконфесійна толерантність - моральноетичний дискурс третього тисячоліття / П.Л. Яроцький // Християнство і мораль. - Тернопіль, 2002. - С. 90.

8. "Querida Amazonia". Післясинодальне Апостольське напоумлення Папи Франциска від 12 лютого 2020 року // Пресслужба Секретаріату Синоду Єпископів УГКЦ (за матеріалами: VaticanNews). - URL:: https://synod.ugcc.ua/data/querida-amazonia-apostolske-napoumlennya-protserkvu-z-amazonskym-oblychchyam-2425/.

\section{Information about the author:}

Bodak V. A.,

Doctor of Philosophy Sciences, Professor at the Philosophy Department named after Valeriy Skotnyi, Drohobych Ivan Franko State Pedagogical University 24, Ivan Franko str., Drohobych, 82100, Ukraine 